\title{
Nanocatalytic Activity of Silver Nanoparticles (Ag-Nps) Fabricated using Camellia sinensis (Linn) Tender Leaf Extract and their Characterization ${ }^{\dagger}$
}

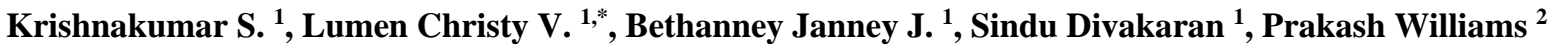 \\ 1 School of Bio and Chemical Engineering, Department of Biomedical Engineering, Sathyabama University, Chennai, \\ Tamilnadu- 600 119, India \\ 2 Department of Botany and Biotechnology, Bishop Moore College, Mavelikara, Kerala-690110, India \\ * Correspondence: lumenchristyv@gmail.com; drkrishnakumar_phd@yahoo.com; \\ $\dagger$ Presented at International e-Conference on Bioengineering for Health and Environment (ICBHE 2020)
}

Received: 5.07.2020; Revised: 10.07.2020; Accepted: 12.07.2020; Published: 15.07.2020

\begin{abstract}
Silver nanoparticles (Ag-NPs) were prepared by the biological reduction method. Green tea extract was taken as a reducing and stabilizing agent and silver nitrate as the metal precursor for nanoparticle synthesis. The formation of the silver nanoparticles was monitored visually and using UVVisible absorption spectroscopy. The synthesized silver nanoparticles were characterized by UV-visible spectroscopy, FTIR, Zeta sizer, Zeta potential, and antimicrobial studies. Silver nanoparticles were also subjected to investigate nanocatalytic activity with standard pancreatic alpha-amylase and bacterial amylase enzyme by the DNS assay method. UV-Vis spectroscopy revealed the formation of silver nanoparticles by exhibiting the typical surface plasmon absorption maxima at $430 \mathrm{~nm}$. Four major functional groups of bio-molecules such as phenol, carboxylic acid, protein, and alkyl group were recorded in FTIR spectra. The size of the nanoparticles ranges between $5 \mathrm{~nm}$ and $150 \mathrm{~nm}$. The average size and size distribution of silver nanoparticles is $59.66 \mathrm{~nm}$. The zeta potential of the silver nanoparticle is negatively charged and rendered as a sharp peak at $-31.7 \mathrm{mV}$. Antimicrobial activity of silver nanoparticles exhibited the highest inhibition against Gram-negative bacteria than Gram-positive bacteria and yeast pathogens. Starch hydrolysis of Ag-NPs was studied with pancreatic alpha-amylase (tailor made), crude and purified bacterial amylase enzyme. The formation of reducing sugar was increased about 40-fold for a purified enzyme, 11-fold for the pancreatic enzyme, and 6-fold for crude bacterial enzyme incorporated with Ag-NPs over control. The present studies recommended that AgNPs have a significant role in the degradation of starch into reducing sugars by acting as a nanocatalyst.
\end{abstract}

Keywords: silver nanoparticles; UV-visible spectroscopy; FTIR; zeta potential; nanocatalyst.

(C) 2020 by the authors. This article is an open-access article distributed under the terms and conditions of the Creative Commons Attribution (CC BY) license (https://creativecommons.org/licenses/by/4.0/).

\section{Funding}

This research received no external funding.

\section{Acknowledgments}

This research has no acknowledgment.

\section{Conflicts of Interest}

The authors declare no conflict of interest. 